\title{
Sikap Anti Korupsi di Kalangan Siswa dan Mahasiswa dalam Mewujudkan Penyelenggaraan Negara Anti Korupsi dan Berbasis Keadilan
}

\author{
Agus Surono*
}

\begin{abstract}
Abstrak
Kebijakan negara dalam melakukan pemberantasan korupsi di Indonesia harus memperhatikan tiga aspek yang berbeda sifatnya, yaitu: politik, hukum, dan korupsi yang menyatu. Lebih lanjut lagi, masyarakat juga sangat menentukan keberhasilan pencegahan terjadinya tindak pidana korupsi. Untuk menumbuhkan budaya hukum masyarakat, perlu dilakukan sejak pendidikan di usia dini dalam berbagai jenjang pendidikan. Upaya yang dapat dilakukan untuk menumbuhkan sikap anti korupsi dapat melalui kampanye/sosialisasi dengan berbagai pihak khususnya kepada siswa pelajar mulai dari siswa SD, siswa SMP, siswa SMA, serta kalangan mahasiswa. Oleh karena itu, seluruh elemen masyarakat termasuk perguruan tinggi dengan bekerja sama dengan pemerintah baik di pusat maupun di daerah harus melaksanakan program tersebut. Menumbuhkan sikap anti korupsi sejak dini tersebut dimulai dengan jenjang pendidikan dari play group ke mahasiswa merupakan langkah konkrit yang dapat dilakukan dalam rangka mewujudkan penyelenggaraan negara yang anti korupsi dan berbasis keadilan.
\end{abstract}

Kata Kunci: anti korupsi, keadilan, mahasiswa, pemberantasan korupsi, pemerintahan yang bersih.

\section{Anti-Corruption Attitude in Students and College Students on Implementing a Justice-Based and Anti-Corruption State}

\begin{abstract}
The state policy in combatting corruption in Indonesia must pay attention to three different aspects, such as: politics, law, and integrated corruption. Furthermore, the people will also determine the success of the prevention of corruption. In order to foster a culture of legal awareness on anti-corruption, it should begin from education at an early age in the various levels of education through campaigns/familiarization with the various parties, especially to students ranging from elementary, junior, senior high school, and all the way to college students. Therefore all elements of society, including universities in cooperation with governments at both central and regional governments, should implement the programs. Thus, fostering an attitude of anti-corruption early on began with an education level from play group to college students is a concrete step that can be done in order to realize the implementation of state anti-corruption and based justice.
\end{abstract}

Keywords: anti-corruption, justice, college students, corruption eradication, clean government.

PADJADJARAN Jurnal IImu Hukum Volume 3 Nomor 2 Tahun 2016 [ISSN 2460-1543] [e-ISSN 2442-9325]

* Dekan Fakultas Hukum Universitas Al-Azhar Indonesia, Kompleks Masjid Agung Al-Azhar, Jl. Sisingamangaraja, Kebayoran Baru, Jakarta Selatan, surono uai@yahoo.com, S.H., M.H. (Universitas Indonesia), Dr. (Universitas Padjadjaran). 


\section{A. Pendahuluan}

Masyarakat dan ketertiban merupakan dua hal yang berhubungan sangat erat bagaikan 2 (dua) sisi dari satu mata uang. Oleh karena itu, dalam masyarakat juga dijumpai berbagai macam norma yang masing-masing memberikan peranan dalam menciptakan ketertiban itu. ${ }^{1}$ Korupsi sebagai bentuk penyalahgunaan kedudukan (jabatan), kekuasaan, kesempatan untuk memenuhi kepentingan diri sendiri dan atau kelompoknya yang bertentangan dengan kepentingan masyarakat. ${ }^{2}$

Indonesia merupakan negara yang berada dalam satu posisi penguasaan trihibrid, yaitu posisi di mana terdapat 3 (tiga) aspek yang berbeda sifatnya, yaitu politik, hukum dan korupsi yang menyatu. ${ }^{3}$ Korupsi merupakan kontruksi sosial bersifat struktural dan diduga korupsi kalangan masyarakat bawah sebagai konstruksi sosial terkait pengaruh korupsi kalangan masyarakat atas (elite sosial ekonomi), seperti pemimpin dan tokoh masyarakat lainnya. ${ }^{4}$

Korupsi merupakan bentuk kejahatan yang sulit pembuktiannya yang tumbuh subur sejalan dengan kekuasaan ekonomi, hukum, dan politik. Layaknya penyakit, maka korupsi ini dikategorikan sebagai penyakit misterius yang kadar penyembuhannya sangat minim dan selalu menjadi uji coba bagi penanggulangannya. Hasilnya pun sering kali sudah dapat diprediksi secara pesimis, yaitu tidak searah dengan kebijakan masyarakat untuk memberantas korupsi. ${ }^{5}$ Secara konseptual, pada negara berkembang, terdapat pemikiran bahwa korupsi ini merupakan bagian dari sistem, sehingga terdapat pula pandangan bahwa penanggulangan yang terpadu adalah memperbaiki sistem yang ada.

Artikulasi sistem ini bermakna komprehensif, bahkan dapat dikatakan sebagai suatu proses yang signifikan. Korupsi sudah menjadi bagian dari sistem yang ada, karenanya usaha maksimal bagi penegakan hukum, khususnya pemberantasan tindak pidana korupsi, harus dilakukan dengan pendekatan sistemik atau systemic approach, apalagi bila pendekatan sistem ini dikaitkan dengan peranan institusi peradilan yang sangat menentukan sebagai salah satu institusi penegakan hukum dalam proses akhir pemberantasan korupsi. ${ }^{6}$

Dua faktor penyebab timbulnya tindak pidana korupsi dipengaruhi faktor-faktor objektif yang mendorong perbuatan korupsi antara lain: tidak adanya ketertiban dalam segala bidang; lemahnya organisasi aparatur pemerintahan, aparatur penegak hukum, dan peradilan maupun aparatur perekonomian negara; lemahnya

\footnotetext{
Satjipto Rahardjo, Ilmu Hukum, Bandung: PT. Citra Aditya Bakti, 2000, hlm. 13.

RB. Soemanto (et.al.), "Pemahaman Masyarakat tentang Korupsi”, Jurnal Yustisia, Vol. 88, 2014, hlm. 80.

Ibid.

Ibid.

Indriyanto Seno Adji, Korupsi dan Penegakan Hukum, Jakarta: Diadit Media, 2009, hlm. 65.

Ibid., hIm. 66.
} 
pengawasan, dan sebagainya. ${ }^{7}$ Korupsi sudah menjadi bagian dari 'sistem' yang ada, karenanya usaha maksimal bagi penegakan hukum, khususnya pemberantasan tindak pidana korupsi, harus dilakukan dengan pendekatan sistem yang dikaitkan dengan peranan institusi peradilan yang sangat menentukan sebagai salah satu institusi penegakan hukum dalam proses akhir pemberantasan korupsi. ${ }^{8}$

Sistem haruslah ditelaah sebagai suatu kesatuan yang meliputi tindakan reevaluasi, reposisi, dan pembaharuan (reformasi) terhadap struktur (structure), substansi (substance) hukum dan khususnya budaya hukum (legal culture) sebagai cermin etika dan integritas penegakan hukum. ${ }^{9}$ Persoalan korupsi sebagai budaya hukum ini berkaitan erat dengan etika, moral masyarakat, khususnya pejabat penegak hukum. Pendekatan struktur dan substansif tidak akan berhasil apabila tidak diikuti secara bersamaan dengan pendekatan budaya dan etika dari penegak hukum itu sendiri yang sering terkontaminasi dengan soal suap. ${ }^{10}$ Pendekatan sistem up-down dalam pemberantasan korupsi merupakan karakter representasi keseriusan negara dalam pemberantasan korupsi. ${ }^{11}$

Pemberantasan korupsi, sebagaimana dinyatakan dalam The Seventh United States Congress on Crime Prevention for Freedom, Justice, Peace and Development 1985, harus dimulai dari upper power class dan upper economic class dengan memperhatikan prinsip-prinsip praduga tidak bersalah. ${ }^{12}$ Berdasarkan beberapa permasalahan di atas, sangat berarti peran kebijakan kriminal (criminal policy) melalui pendekatan non-penal sebagai bagian dari pencegahan tindak pidana korupsi, antara lain melalui pendidikan dari berbagai level mulai dari sekolah dasar (SD), sekolah menengah pertama (SMP), sekolah menengah atas (SMA), Mahasiswa, pers (sebagai social power) dan institusi kenegaraan (sebagai political power)..$^{13}$

Dalam Pasal 1 angka 1 Bab Ketentuan Umum Undang-Undang Nomor 30 Tahun 2002 tentang Komisi Pemberantasan Tindak Pidana Korupsi (UU KPK), disebutkan tentang pengertian tindak pidana korupsi: ${ }^{14}$

"Tindak Pidana Korupsi adalah tindak pidana sebagaimana dimaksud dalam Undang-Undang Nomor 31 tahun 1999 tentang Pemberantasan Tindak Pidana Korupsi sebagaimana telah diubah dengan UndangUndang Nomor 20 Tahun 2001 tentang Perubahan atas Undang-

7 Lilik Mulyadi, Tindak Pidana Korupsi di Indonesia (Normatif, Teoritis, Praktik dan Masalahnya), Bandung: PT. Alumni, 2007, hlm. 2.

Ibid.

Ibid.

lbid., hlm. 68.

Ibid.

lbid., hlm. 69.

Ibid.

14 Ermansjah Djaja, Memberantas Korupsi Bersama KPK (Komisi Pemberantasan Korupsi), Jakarta: Sinar Grafika, 2013, hlm. 25. 
Undang Nomor 31 Tahun 1999 tentang Pemberantasan Tindak Pidana Korupsi."

Dengan demikian dapat dijabarkan mengenai pengertian dari 'tindak pidana korupsi' adalah semua ketentuan hukum materiil yang terdapat pada UndangUndang Nomor 31 Tahun 1999 tentang Pemberantasan Tindak Pidana Korupsi (UU Tipikor) sebagaimana telah diubah dengan Undang-Undang Nomor 20 tahun 2001 tentang Perubahan atas Undang-Undang Nomor 31 Tahun 1999 tentang Pemberantasan Tindak Pidana Korupsi (UU Tipikor 2001) yang diatur dalam PasalPasal 2, 3, 4, 5, 6, 7, 8, 9, 10, 11, 12, 12A, 12B, 13, 14, 15, 16, 21, 22, 23, dan 24. ${ }^{15}$ Ditambah lagi dengan tindak pidana korupsi sebagaimana ditentukan dalam Pasal 14 UU Tipikor yang menyatakan bahwa: "Setiap orang yang melanggar ketentuan undang-undang yang secara tegas menyatakan bahwa pelanggaran terhadap ketentuan undang-undang tersebut sebagai tindak pidana korupsi berlaku ketentuan yang diatur dalam undang-undang". ${ }^{16}$

Pengertian pemberantasan tindak pidana korupsi dapat dijelaskan dalam Pasal 1 angka 3 Bab Ketentuan Umum UU KPK: ${ }^{17}$

"Pemberantasan Tindak Pidana Korupsi adalah serangkaian tindakan untuk mencegah dan memberantas tindak pidana korupsi melalui upaya koordinasi, supervisi, monitor, penyelidikan, penyidikan, penuntutan dan pemeriksaan di sidang pengadilan, dengan peran serta masyarakat berdasarkan peraturan perundang-undangan yang berlaku."

Memperhatikan tentang pengertian pemberantasan tindak pidana korupsi, yaitu serangkaian tindakan untuk mencegah dan memberantas tindak pidana korupsi melalui upaya koordinasi, supervisi, monitor, penyelidikan, penyidikan, penuntutan, dan pemeriksaan di sidang pengadilan. ${ }^{18}$ Peran serta masyarakat berdasarkan peraturan perundang-undangan yang berlaku dalam pemberantasan tindak pidana, sejalan dengan ketentuan Pasal 41 dan Pasal 42 Bab V UU Tipikor. ${ }^{19}$ Pasal 41 UU Tipikor menyatakan bahwa:

1) Masyarakat dapat berperan serta membantu upaya pencegahan dan pemberantasan tindak pidana korupsi;

2) Peran serta masyarakat sebagaimana dimaksud dalam ayat (1) diwujudkan dalam bentuk:

a. Hak mencari, memperoleh, dan memberikan informasi adanya dugaan telah terjadi tindak pidana korupsi;

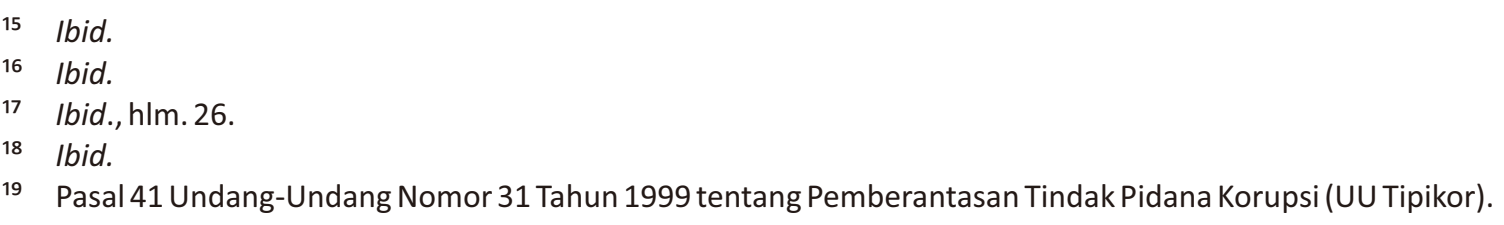


b. Hak untuk memperoleh pelayanan dalam mencari, memperoleh, dan memberikan informasi adanya dugaan telah terjadi tindak pidana korupsi kepada penegak hukum yang menangani perkara tindak pidana korupsi;

c. Hak menyampaikan saran dan pendapat secara bertanggung jawab kepada penegak hukum yang menangani perkara tindak pidana korupsi;

d. Hak untuk memperoleh jawaban atas pertanyaan tentang laporannya yang diberikan kepada penegak hukum dalam waktu paling lama 30 (tiga puluh) hari;

e. Hak untuk memperoleh perlindungan hukum dalam hal:

1. Melaksanakan haknya sebagaimana dimaksud dalam huruf a, b, dan c;

2. Diminta hadir dalam proses penyelidikan, penyidikan, dan di sidang pengadilan sebagai saksi pelapor;

3. Masyarakat sebagaimana dimaksud dalam ayat (1) mempunyai hak dan tanggung jawab dalam upaya pencegahan dan pemberantasan tindak pidana korupsi;

4. Hak dan tanggung jawab sebagaimana dimaksud dalam ayat (2) dan ayat (3) dilaksanakan dengan berpegang teguh pada asas-asas atau ketentuan yang diatur dalam peraturan perundang-undangan yang berlaku dan dengan menaati norma agama dan norma sosial lainnya;

5. Ketentuan mengenai tata cara pelaksanaan peran serta masyarakat dalam pencegahan dan pemberantasan tindak pidana korupsi sebagaimana dimaksud dalam pasal ini, diatur lebih lanjut dengan Peraturan Pemerintah.

Adapun ketentuan Pasal 8 ayat 1 Undang-Undang Nomor 28 Tahun 1999 tentang Penyelenggaraan Negara yang Bersih dan Bebas dari Korupsi, Kolusi, Nepotisme (UU KKN), menyatakan bahwa peran serta masyarakat dalam penyelenggaraan negara merupakan hak dan tanggung jawab masyarakat untuk ikut mewujudkan penyelenggaraan negara yang bersih. ${ }^{20}$ Bentuk peran serta masyarakat telah pula diatur lebih lanjut dalam Pasal 2 Peraturan Pemerintah Nomor 68 Tahun 1999 tentang Tata Cara Pelaksanaan Peran Serta Masyarakat dalam Penyelenggaraan Negara, yang menyatakan bahwa peran serta masyarakat dalam penyelenggaraan negara untuk mewujudkan penyelenggara negara yang bersih dilaksanakan dalam bentuk:

1) hak mencari, memperoleh, dan memberikan informasi mengenai penyelenggara negara;

2) hak memperoleh pelayanan yang sama dan adil dari penyelenggara negara;

3) hak menyampaikan saran dan pendapat secara bertanggung jawab terhadap

20 Pasal 8 ayat (1) Undang-Undang Nomor 28 Tahun 1999 tentang Penyelenggaraan Negara yang Bersih dan Bebas dari Korupsi, Kolusi, Nepotisme (UU KKN). 
kebijakan penyelenggara negara; dan

4) hak memperoleh perlindungan dalam hal:

a. Melaksanakan haknya sebagaimana dimaksud dalam hurufa, b, dan c;

b. Meminta hadir dalam proses penyelidikan, penyidikan, dan di sidang pengadilan sebagai saksi pelapor, saksi, atau saksi ahli sesuai dengan ketentuan peraturan perundang-undangan yang berlaku. ${ }^{21}$

Selanjutnya Paragraf 12 Penjelasan UU Tipikor ${ }^{22}$ menyatakan bahwa masyarakat dapat berperan serta untuk membantu upaya pencegahan dan pemberantasan tindak pidana korupsi, dan terhadap anggota masyarakat yang berperan serta tersebut diberikan perlindungan hukum dan penghargaan. Salah satu langkah dalam upaya pencegahan tindak pidana korupsi dilakukan dengan menumbuhkan sikap anti korupsi, sedini mungkin kepada siswa SD, siswa SMP, siswa SMA, serta mahasiswa.

Upaya menumbuhkan sikap anti korupsi sejak dini ini dimaksudkan sebagai upaya untuk mewujudkan penyelenggaraan negara yang anti korupsi dan berbasis keadilan pada masa yang akan datang karena kelak siswa-siswi dan mahasiswa tersebut akan menggantikan generasi yang ada saat ini dalam berbagai profesi yang akan ditekuni baik pemerintah maupun swasta, serta masyarakat pada umumnya. Berdasarkan latar belakang masalah tersebut di atas dapat dikemukakan identifikasi masalah berkaitan dengan bagaimana bentuk pencegahan dan pemberantasan tindak pidana korupsi dalam mewujudkan penyelenggaraan negara anti korupsi dan berbasis keadilan di Indonesia, serta bagaimana menumbuhkan sikap anti korupsi bagi siswa dan mahasiswa dalam mewujudkan penyelenggaraan negara anti korupsi dan berbasis keadilan.

\section{B. Pencegahan dan Pemberantasan Tindak Pidana Korupsi dalam Mewujudkan Penyelenggaran Negara Anti Korupsi dan Berbasis Keadilan}

Negara Indonesia merupakan negara hukum (rechtstaat) sebagaimana Pasal 1 ayat (3) Undang-Undang Dasar 1945 (UUD 1945) Amandemen Ketiga yang mempunyai ciri menjunjung tinggi sistem hukum yang menjamin kepastian hukum (rechts zekerheids) dan perlindungan terhadap hak asasi manusia (human rights). Pada dasarnya, suatu negara yang berdasarkan atas hukum harus menjamin persamaan (equality) setiap individu, termasuk kemerdekaan individu untuk menggunakan hak asasinya. ${ }^{23}$ Oleh karena itu, dalam suatu negara hukum, kedudukan dan hubungan individu dengan negara senantiasa dalam keseimbangan. ${ }^{24}$ Partisipasi masyarakat

21 Pasal 2 Peraturan Pemerintah Nomor 68 Tahun 1999 tentang Tata Cara Pelaksanaan Peran Serta Masyarakat dalam Penyelenggaraan Negara (PP 68/1999).

22 Tambahan Lembaran Negara Republik Indonesia Tahun 1999 Nomor 387.

23 Sudargo Gautama, Pengertian tentang Negara Hukum, Bandung: Penerbit Alumni, 1983, hlm. 3.

24 Ibid. 
sangat dibutuhkan dalam pemberantasan tindak pidana korupsi, karena mengingat bahwa masyarakatlah yang paling dirugikan dari korupsi. ${ }^{25}$

Pemerintahan yang bersih tentu menciptakan pelayanan publik yang bersifat menolong, terbuka, bertanggung jawab, responsif, dan adil. ${ }^{26}$ Berputarnya roda partisipasi masyarakat akan seirama dengan perubahan di lingkungan pemerintahan. ${ }^{27}$ Agar upaya memerangi korupsi membawa manfaat besar, maka yang pertama dan terutama dilakukan adalah membentuk kesadaran dalam diri masyarakat bahwa mereka adalah 'majikan' sedangkan pemerintah adalah 'pelayan'. ${ }^{28}$

Strategi pemberantasan korupsi dapat dilakukan dengan hal-hal sebagai berikut:29 Pertama, strategi preventif, yakni strategi yang sifatnya mencegah terjadinya tindak pidana korupsi. Kedua, strategi detektif, yakni strategi mendeteksi apakah telah terjadi tindak pidana korupsi. Ketiga, strategi advokasi, yakni strategi membangun sistem yang dapat menyelesaikan kasus-kasus korupsi secara hukum.

Adapun pilar-pilar penting penegakan hukum, khususnya dalam rangka pemberantasan tindak pidana korupsi yang perlu mendapat perhatian, yakni: ${ }^{30}$

\section{Peraturan Perundang-Undangan}

Secara objektif, norma hukum mencakup hukum formal dan hukum materiel. Hukum formal (tertulis) antara lain: Undang-Undang Nomor 8 Tahun 1981 tentang Hukum Acara Pidana, UU Tipikor, dan peraturan perundang-undangan terkait. Hukum tidak tertulis mencakup pula pengertian nilai-nilai keadilan yang hidup dalam masyarakat. Indonesia sebagai negara peratifikasi United Nation Convention Against Corruption (UNCAC) Tahun 2003, maka harmonisasi peraturan perundangan nasional terkait pemberantasan tindak pidana korupsi dengan konvensi tersebut, merupakan acuan utama arah pemberantasan korupsi ke depan, mengingat tindak pidana korupsi merupakan transnational crime.

\section{Aparatur Penegak Hukum}

Arah pemberantasan korupsi ke depan harus memperhatikan 2 (dua) hal: pertama, tugas dan fungsi penyelidikan/penyidikan. Permasalahan yang sering muncul terkait adanya beberapa instansi penyelidik/penyidik tindak pidana korupsi yakni Kepolisian, Kejaksaan dan KPK adalah adanya tumpang tindih dalam pelaksanaan penyelidikan/penyidikan. Kedua, tugas dan fungsi penuntutan tindak pidana

\footnotetext{
25 Jhon Rivel, “Membangun partisipasi masyarakat dalam memerangi korupsi”, http://www.kompasiana.com/ rivel/membangun-partisipasi-masyarakat-dalam-memerangi-korupsi 552988646ea8348068552d76, diakses 26 September 2016

26 Ibid.

27 Ibid.

28 Ibid.

29 Ibid.

30 Romli Atmasasmita, Globalisasi dan Kejahatan Bisnis, Cetakan Pertama, Jakarta: Kencana Prenada Media, 2010, hlm. 17.
} 
korupsi. Dalam praktiknya adanya penuntutan yang dilakukan oleh dua lembaga yang berbeda akan memunculkan disparitas tuntutan pidana.

\section{Sarana dan Prasarana}

Berkaitan sarana dan prasarana, yang menyangkut beberapa hal: pertama, persoalan teknis yuridis yang seharusnya diperkirakan, diantaranya menyangkut kewenangan pemberian izin dan persetujuan penggeledahan/penyitaan, perpanjangan penahan pengadilan negeri, serta pemeriksaan praperadilan perkaraperkara tindak pidana korupsi terjadi, apakah berada pada pengadilan negeri setempat di mana tindak pidana korupsi terjadi ataukah pada pengadilan Tipikor. Kedua, permasalahan tenaga, waktu dan biaya persidangan perkara tindak pidana korupsi. Ketiga, asas Rutan/Lapas yang terbatas. Keempat, anggaran penegakan hukum yang minim, dan kelima, kesejahteraan aparat penegak hukum.

\section{Peran Serta Masyarakat}

Peran serta masyarakat dimulai dari proses mengenali masalah, merencanakan kegiatan, hingga melaksanakan kegiatan menjadi bagian yang sangat penting agar dapat melaksanakan peran serta untuk pencegahan tindak pidana korupsi. Peran serta masyarakat harus sesuai dengan beberapa asas, antara lain asas keseimbangan, yaitu keseimbangan antara tujuan hukum menuju terciptanya keadilan dan kepastian di satu sisi dengan terwujudnya ketertiban hukum dalam masyarakat. Selanjutnya asas keadilan dalam penegakan hukum bagi mereka yang telah melakukan tindak pidana korupsi agar dapat berjalan dengan seadil-adilnya sangat diperlukan peran serta masyarakat dalam penegakan hukum tersebut.

Lalu yang terakhir asas kepastian hukum yang memberikan kepastian hukum tentang pemberian sanksi pidana oleh negara kepada pelaku tindak pidana korupsi sangat diperlukan peranan masyarakat dalam mengawasi apakah penegakan hukumnya telah mencerminkan asas kepastian hukum. ${ }^{31}$ Di samping itu, tanpa kepastian hukum dan ketertiban masyarakat yang dijelmakan oleh hukum, manusia tidak mungkin mengembangkan bakat-bakat dan kemampuan yang diberikan Tuhan kepadanya secara optimal di dalam masyarakat tempat ia hidup. ${ }^{32}$ Lebih lanjut mengenai peran serta masyarakat dalam menumbuhkan sikap anti korupsi dalam mewujudkan penyelenggaraan negara anti korupsi dan berbasis keadilan yang merupakan bagian dari pencegahan tindak pidana korupsi akan dijelaskan lebih lanjut dalam sub judul berikutnya.

31 Ibid.

32 Mochtar Kusumaatmadja, Fungsi dan Perkembangan Hukum Dalam Pembangunan Nasional, Jakarta: Bina Cipta, 1976, hlm. 3. 


\section{Konsep Negara Kesejahteraan, Keadilan, dan Budaya Hukum dalam Menumbuhkan Budaya Anti Korupsi sebagai Upaya Pencegahan Tindak Pidana Korupsi}

\section{Teori Negara Kesejahteraan (Welfare State)}

Negara kesejahteraan menurut Bagir Manan adalah negara atau pemerintah yang tidak semata-mata sebagai penjaga keamanan atau ketertiban masyarakat, tetapi juga pemikul utama tanggung jawab mewujudkan keadilan sosial, kesejahteraan umum, dan sebesar-besar kemakmuran rakyat. ${ }^{33}$ Unsur-unsur terpenting dari negara hukum materiil atau negara kesejahteraan (welfare state) adalah: ${ }^{34}$

1. Jaminan terhadap hak-hak asasi manusia;

2. Pemisahan atau pembagian kekuasaan;

3. Legalitas pemerintah;

4. Peradilan yang bebas dan tidak memihak; dan

5. Terwujudnya kesejahteraan umum warga negara.

Pemerintah dalam negara kesejahteraan diberi tugas membangun kesejahteraan umum dalam berbagai lapangan dengan konsekuensi pemberian kemerdekaan kepada administrasi negara dalam menjalankannya. Negara dituntut untuk memperluas tanggung jawabnya kepada masalah-masalah sosial ekonomi yang dihadapi rakyat, bahkan perlu untuk melakukan intervensi dalam berbagai masalah sosial dan ekonomi untuk menjamin terciptanya kesejahteraan bersama dalam masyarakat. ${ }^{35}$ Secara konstitutif, penegasan bahwa Indonesia menganut teori negara hukum disebutkan dalam Pasal 1 ayat (3) UUD 1945 amandemen ke-4 yaitu 'Negara Indonesia adalah negara hukum'. Pengaturan prinsip negara hukum dalam batang tubuh, menjadikannya sebagai constitutional norm yang memiliki daya norma atau kaidah lebih kuat dan berfungsi sebagai payung bagi bab-bab selanjutnya. ${ }^{36}$

Negara Republik Indonesia dikonsepsikan sebagai negara hukum yang menganut negara kesejahteraan berdasarkan penafsiran atas cita-cita negara. Tujuan atau cita-cita negara hukum Indonesia adalah membentuk masyarakat adil dan makmur berdasarkan Pancasila yang secara definitif dituangkan dalam alinea ke-4 pembukaan UUD 1945 yang meliputi:

33 Bagir Manan, Politik Perundang-Undangan dalam Rangka Mengantisipasi Liberalisasi Perekonomian, Bandar Lampung: FH-UNILA, 1996, hIm. 16.

34 B. Hestu Cipto Handoyo, Hukum Tata Negara Indonesia, Cetakan ke-5, Yogyakarta: Universitas Atma Jaya, 2013, hlm. 21.

35 Muntoha, Negara Hukum Indonesia Pasca Perubahan UUD 1945, Cetakan ke-1, Yogyakarta: Kaukaba Dipantara, 2013, hlm. 7.

36 Susi Dwi Harijanti, "Negara Hukum dalam Undang-Undang Dasar 1945" dalam buku Negara Hukum yang Berkeadilan Kumpulan Pemikiran Dalam Rangka Purnabakti Prof Dr. H. Bagir Manan, S.H., M.H., Cetakan ke-1, yang disusun oleh Susi Dwi Harijanti, (et.al.) (eds), Bandung: Pusat Studi Kebijakan Negara Fakultas Hukum Universitas Padjadjaran, 2011, hlm. 95. 
1. Melindungi segenap bangsa dan seluruh tumpah darah Indonesia;

2. Memajukan kesejahteraan umum;

3. Mencerdaskan kehidupan bangsa; dan

4. Ikut melaksanakan ketertiban dunia berdasarkan kemerdekaan, perdamaian abadi, dan keadilan sosial.

Tujuan negara Indonesia tersebut harus diarahkan pada cita hukum sebagai kerangka keyakinan dan berpijak pada Pancasila sebagai pandangan hidup bangsa yang berarti nilai-nilai yang terkandung dalam Pancasila dijadikan sebagai dasar dan pedoman dalam mengatur sikap dan tingkah laku manusia Indonesia dalam hubungannya dengan tujuan masyarakat dan alam semesta, serta dalam segala bidang kehidupan yang meliputi bidang ekonomi, politik, sosial budaya, hukum, pertahanan dan keamanan. ${ }^{37}$

Negara kesejahteraan sebagai organisasi tertinggi wajib menyelenggarakan kepentingan umum dengan menentukan arah kebijakan berbagai kehidupan bangsa terutama di bidang hukum, ekonomi, dengan mengatur dan mengarahkan kegiatan ekonomi sesuai dengan prinsip perekonomian bangsa. ${ }^{38}$ Pembangunan hukum di Indonesia harus diarahkan pada terwujudnya sistem hukum yang mengabdi pada kepentingan nasional terutama rakyat melalui penyusunan materi hukum yang bersumber pada Pancasila sebagai sumber filosofinya dan UUD 1945 sebagai dasar konstitusionalnya, serta aspirasi rakyat sebagai sumber materiil. ${ }^{39}$

Dalam konteks pencegahan dan pemberantasan tindak pidana korupsi, pembentukkan UU Tipikor di Indonesia harus mengacu pada tujuan dan cita-cita bangsa yakni tegaknya negara hukum yang bersumber pada Pancasila dan UUD 1945 yang bersifat demokratis dan berkeadilan sosial dengan menegakkan kepastian hukum dan mencapai keadilan di segala bidang kehidupan guna mewujudkan masyarakat yang adil, makmur, dan sejahtera. Penyelenggaraan Indonesia sebagai negara hukum harus dibangun sistem hukum nasional yang mencakup: 40

a. Bertujuan untuk menjamin integrasi bangsa dan negara baik secara ideologis maupun secara teritorial;

b. Berdasarkan atas kesepakatan rakyat baik diputuskan melalui musyawarah mufakat maupun pemungutan suara, dan hasilnya dapat diuji konsistensinya secara yuridis dengan rehtsidee;

c. Bertujuan untuk mewujudkan kesejahteraan umum dan keadilan sosial; dan

37 Syahrial Syarbaini, Pendidikan Pancasila (Implementasi Nilai-Nilai Karakter Bangsa) Di Perguruan Tinggi, Cetakan ke-4, Bogor: Ghalia Indonesia, 2012, hlm. 17-21.

38 C.S.T Kansil dan Christine S.T Kansil, Hukum Tata Negara Republik Indonesia, Jakarta: Rineka Cipta, 2000, hlm. 20.

39 Ani Sri Rahayu, Pendidikan Pancasila \& Kewarganegaraan (PPKn), Cetakan ke-1, Jakarta: Bumi Aksara, 2013, hlm. 85.

40 C.S.T Kansil dan Christine S.T Kansil, Op.cit., hlm. 10-11. 
d. Bertujuan untuk mewujudkan toleransi beragama yang berkeadaban dalam arti tidak boleh mengistimewakan atau mendiskriminasikan kelompok-kelompok atau golongan tertentu.

\section{Teori Keadilan}

Keadilan merupakan salah satu tujuan terpenting dari setiap sistem hukum, di samping masih ada tujuan hukum yang lainnya yaitu kepastian hukum, kemanfaatan, dan ketertiban. ${ }^{41}$ Dalam prinsip-prinsip fundamental organisasi negara secara tersirat juga menyentuh prinsip-prinsip yang fundamental yaitu pemisahan kekuasaan, pengujian oleh badan peradilan, prinsip legalitas, prosedur yang adil, kepastian hukum, proporsionalitas dan lain-lain. ${ }^{42}$ Konsep keadilan sebenarnya sudah banyak dikemukakan oleh para ahli karena keadilan sesung-guhnya sesuatu yang sangat dekat dengan pemenuhan hak dan kepentingan manusia. ${ }^{43}$ Kata adil atau keadilan merupakan kombinasi dari nilai-nilai moral dan sosial yang merupakan pengejawantahan dari fairness (kejujuran/keadilan/kewajaran); balance (keseimbangan); temperance (menahan diri); dan straightforwardness (kejujuran). ${ }^{44}$

Di Indonesia, prinsip keadilan secara formal tertera dalam Pembukaan UUD 1945 yang menyatakan: (1) bahwa kemerdekaan itu hak segala bangsa,... karena tidak sesuai dengan perikemanusiaan dan 'perikeadilan', (2)...kemerdekaan negara Indonesia yang merdeka, bersatu, berdaulat, 'adil' dan makmur, (3)...untuk memajukan kesejahteraan umum...dan 'keadilan sosial', (4)...susunan negara Republik Indonesia yang berdasarkan kepada...'keadilan sosial' bagi seluruh rakyat Indonesia. Prinsip-prinsip tersebut pada hakekatnya merupakan jaminan secara formal terhadap 'rasa keadilan' dan juga 'keadilan sosial' bagi seluruh rakyat Indonesia. Penjabaran selanjutnya secara formal juga tertuang dalam pasal-pasal dalam UUD 1945 misalnya dalam Pasal 24 ayat (1), Pasal 28 D ayat (1), dan Pasal 28 D ayat (2). ${ }^{45}$ Dalam Pasal 5 ayat (1) Undang-Undang Nomor 48 Tahun 2009 tentang Kekuasaan Kehakiman (UU Kekuasaan Kehakiman) ditegaskan bahwa hakim wajib menggali, mengikuti, dan memahami nilai-nilai hukum dan rasa keadilan yang hidup dalam masyarakat. Pertimbangan hukum yang demikian, tidak sekedar formallegal-normatif, melainkan juga substantif-moral-justice. ${ }^{46}$ Dalam kaitannya dengan penegakan hukum tindak pidana korupsi Indonesia, maka diperlukan penegakan hukum yang berkeadilan.

41 Bismar Siregar, Hukum Hakim dan Keadilan Tuhan, Jakarta: Gema Insani Press, 1995, hlm. 19-20.

42 Ibid.

43 Efran Helmi Juni, Filsafat Hukum, Cetakan ke-1, Bandung: Pustaka Setia, 2012, hlm. 405.

44 Agus Santoso, Hukum, Moral, Dan Keadilan Sebuah Kajian Filsafat Hukum, Cetakan ke-1, Jakarta: Prenada Media Group, 2012, hlm. 94.

45 Darji Darmodiharjo dan Sidharta, Pokok-Pokok Filsafat Hukum Apa dan Bagaimana Filsafat Hukum Indonesia, Jakarta: Gramedia Pustaka Utama, 2006, hlm. 166.

46 Ahmad Sudiro dan Deni Bram, Hukum dan Keadilan (Aspek Nasional \& Internasional), Cetakan ke-1, Jakarta: Raja Grafindo Persada, 2013, hlm. 135. 


\section{Teori Budaya Hukum}

Untuk dapat memahami persoalan yang berkaitan dengan hukum secara lebih baik, maka hukum hendaknya dilihat sebagai suatu sistem. Pengertian dasar yang terkandung dalam sistem tersebut meliputi 2 (dua) hal: ${ }^{47}$ Pertama, yaitu sebagai sesuatu wujud atau entitas, yaitu sistem biasa dianggap sebagai suatu himpunan bagian yang saling berkaitan, yang membentuk satu keseluruhan yang rumit atau kompleks tetapi merupakan satu kesatuan. Kedua, sistem mempunyai makna metodologik yang dikenal dengan pengertian umum pendekatan sistem (system approach).

Apabila suatu sistem itu ditempatkan pada pusat pengamatan yang demikian, maka pengertian-pengertian dasar yang terkandung didalamnya adalah sebagai berikut: 48

a. Sistem itu selalu berorientasi pada suatu tujuan;

b. Keseluruhan adalah lebih dari sekadar jumlah dari bagian-bagiannya (wholism);

c. Suatu sistem berinteraksi dengan sistem yang lebih besar, yaitu lingkungannya (keterbukaan sistem);

d. Bekerjanya bagian-bagian dari sistem itu menciptakan sesuatu yang berharga (transformasi);

e. Masing-masing bagian harus cocok satu sama lain (keterhubungan);

Dengan demikian, terdapat kekuatan pemersatu yang mengikat sistem itu (mekanisme kontrol).

\section{Menumbuhkan Sikap Anti Korupsi di Kalangan Siswa dan Mahasiswa dalam Mewujudkan Penyelenggaraan Negara Anti Korupsi dan Berbasis Keadilan}

Sebagaimana diuraikan pada sub judul sebelumnya, bahwa pencegahan tindak pidana korupsi dapat dilakukan melalui upaya menumbuhkan sikap anti korupsi. Dalam rangka menumbuhkan sikap anti korupsi di Indonesia dapat dilakukan melalui pendidikan kepada siswa-siswi sekolah dasar (SD), siswa-siswi sekolah menengah pertama (SMP), siswa-siswi sekolah menengah atas (SMA), dan juga terhadap para mahasiswa. Adapun uraian mengenai data-data statistik terhadap jumlah siswa-siswa dan mahasiswa secara nasional yang dapat diberikan materi tentang sikap anti korupsi dapat diuraikan sebagai berikut:

\section{Siswa Sekolah Dasar}

Berdasarkan data yang bersumber dari Biro Pusat Statistik (BPS) terkait jumlah SD, siswa dan guru, dalam kurun waktu 2014 dapat ditunjukkan sebagai berikut: ${ }^{49}$

47 Otje Salman S., H.R. dan Anthon F. Susanto, Teori Hukum, Mengingat, Mengumpulkan dan Membuka Kembali, Bandung: PT Refika Aditama, 2004, hlm. 84.

48 Satjipto Rahardjo, Op.cit., hlm. 48-49.

49 Biro Pusat Statistik (BPS), "Jumlah Sekolah, Guru, Murid Sekolah Dasar (SD) di Bawah Kementerian Pendidikan dan Kebudayaan Menurut Provinsi 2011/2012-2013/2014", https://www.bps.go.id/linkTabelStatis/ view/id/1810, diakses tanggal 8 Oktober 2016. 
jumlah SD sebanyak 148.272 sekolah, jumlah guru sebanyak 1.539 .819 orang, jumlah murid SD sebanyak 26.504.160 orang. Data tersebut didasarkan pada jumlah provinsi sebanyak 34 provinsi, di mana satu provinsi Kalimantan Utara tidak didapatkan data karena pada kurun waktu tersebut masih belum menjadi provinsi tersendiri hasil pemekaran Kalimantan Timur.

Selanjutnya apabila dijumlahkan, jumlah antara guru dan murid SD berjumlah 28.504.160 orang yang sangat potensial untuk mengkampanyekan sikap anti korupsi sejak dini, khususnya kepada siswa-siswa SD. Guru-guru tersebut dapat ditugaskan untuk mengkampanyekan sikap anti korupsi, setelah terlebih dahulu mendapatkan pelatihan oleh Perguruan Tinggi sebagai bagian dari bentuk pengabdian kepada masyarakat. Adapun materi sikap anti korupsi dapat dilakukan secara sistematis melalui mata pelajaran dan/atau materi mata pelajaran tertentu yang memasukkan subtansi tentang pentingnya sikap anti korupsi, seperti dalam mata pelajaran Agama, Pancasila, dan Kewarganegaraan dan materi pelajaran lainnya yang relevan.

\section{Siswa Sekolah Menengah Pertama}

Berdasarkan data yang bersumber dari BPS terkait jumlah SMP, siswa dan guru, dalam kurun waktu 2014 dapat ditunjukkan sebagai berikut: ${ }^{50}$ jumlah SMP sebanyak 35.488 sekolah, jumlah guru sebanyak 596.089 orang, jumlah murid SMP sebanyak 9.715.203 orang. Data tersebut didasarkan pada jumlah provinsi sebanyak 34 provinsi, di mana satu provinsi Kalimantan Utara tidak didapatkan data karena pada kurun waktu tersebut masih belum menjadi provinsi tersendiri hasil pemekaran Kalimantan Timur.

Selanjutnya apabila dijumlahkan jumlah antara guru dan murid SD berjumlah 10.311.292 orang yang sangat potensial untuk mengkampanyekan sikap anti korupsi sejak dini khususnya kepada siswa-siswa SMP. Guru-guru tersebut dapat ditugaskan untuk mengkampanyekan sikap anti korupsi, setelah terlebih dahulu mendapatkan pelatihan oleh Perguruan Tinggi sebagai bagian dari bentuk pengabdian kepada masyarakat. Adapun materi sikap anti korupsi dapat dilakukan secara sistematis melalui mata pelajaran dan/atau materi mata pelajaran tertentu yang memasukkan subtansi tentang pentingnya sikap anti korupsi, seperti dalam mata pelajaran Agama, Pancasila, dan Kewarganegaraan dan materi pelajaran lainnya yang relevan.

\section{Siswa Sekolah Menengah Atas (SMA)}

Berdasarkan data yang bersumber dari BPS terkait jumlah SMA, siswa dan guru,

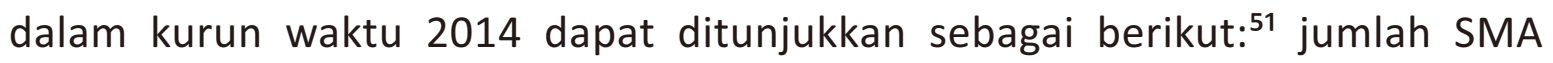

50 BPS, "Jumlah Sekolah, Guru, Murid Sekolah Menengah Pertama (SMP) di Bawah Kementerian Pendidikan dan Kebudayaan Menurut Provinsi 2011/2012-2013/2014", https://www.bps.go.id/linkTabelStatis/view/id/1835, diakses tanggal 8 Oktober 2016.

51 BPS, "Jumlah Sekolah, Guru, Murid Sekolah Menengah Atas (SMA) di Bawah Kementerian Pendidikan dan 
sebanyak 12.409 sekolah, jumlah guru sebanyak 278.711 orang, dan jumlah murid SMA sebanyak 4.292.288 orang. Data tersebut didasarkan pada jumlah provinsi sebanyak 34 provinsi, di mana satu provinsi Kalimantan Utara tidak didapatkan data karena pada kurun waktu tersebut masih belum menjadi provinsi tersendiri hasil pemekaran Kalimantan Timur.

Selanjutnya apabila dijumlahkan, jumlah antara guru dan murid SMA berjumlah 4.570.999 orang yang sangat potensial untuk mengkampanyekan sikap anti korupsi sejak dini khususnya kepada siswa-siswa SMA. Guru-guru tersebut dapat ditugaskan untuk mengampanyekan sikap anti korupsi, setelah terlebih dahulu mendapatkan pelatihan oleh Perguruan Tinggi sebagai bagian dari bentuk pengabdian kepada masyarakat. Adapun materi sikap anti korupsi dapat dilakukan secara sistematis melalui mata pelajaran dan/atau materi mata pelajaran tertentu yang memasukkan subtansi tentang pentingnya sikap anti korupsi, seperti dalam mata pelajaran Agama, Pancasila, dan Kewarganegaraan dan materi pelajaran lainnya yang relevan.

\section{Mahasiswa}

Berdasarkan data yang bersumber dari BPS terkait jumlah perguruan tinggi di bawah Dikti, mahasiswa dan dosen, dalam kurun waktu 2014 untuk perguruan tinggi negeri dapat ditunjukkan sebagai berikut: ${ }^{52}$ jumlah universitas sebanyak 99 , jumlah dosen sebanyak 87.533 orang, jumlah mahasiswa sebanyak 1.827.240 orang. Selanjutnya untuk perguruan tinggi swasta yang berada di bawah Dikti adalah sebagai berikut: jumlah Universitas sebanyak 3181, jumlah dosen sebanyak 143.382 orang, dan jumlah mahasiswa sebanyak 4.012.347 orang.

Adapun jumlah perguruan tinggi di bawah Kementerian Agama, mahasiswa dan dosen, dalam kurun waktu 2014 untuk perguruan tinggi negeri dapat ditunjukkan sebagai berikut: ${ }^{53}$ jumlah universitas sebanyak 53, jumlah dosen sebanyak 12.002 orang, jumlah mahasiswa sebanyak 341.315 orang. Selanjutnya untuk perguruan tinggi swasta yang berada di bawah Kementerian Agama adalah jumlah universitas sebanyak 625, jumlah dosen sebanyak 14.669 orang, dan jumlah mahasiswa sebanyak 272.350 orang.

Dosen-dosen yang mengajar mata kuliah baik mata kuliah wajib universitas maupun mata kuliah dapat memasukkan materi tentang sikap anti korupsi, antara lain dalam berbagai mata kuliah seperti Pendidikan Agama, PPKN, Kewirausahaan,

Kebudayaan Menurut Provinsi 2011/2012-2013/2014", https://www.bps.go.id/linkTabelStatis/view/id/1837, diakses tanggal 8 Oktober 2016.

52 BPS, "Jumlah Perguruan Tinggi, Mahasiswa, dan Tenaga Edukatif (Negeri dan Swasta) di Bawah Kementerian Pendidikan dan Kebudayaan Menurut Provinsi 2013/2014", https://www.bps.go.id/linkTabelStatis/ view/id/1839, diakses tanggal 8 Oktober 2016.

53 BPS, "Jumlah Perguruan Tinggi, Mahasiswa, dan Tenaga Edukatif (Negeri dan Swasta) di Bawah Kementerian Agama Menurut Provinsi 2013/2014", https://www.bps.go.id/linkTabelStatis/view/id/1840, diakses tanggal 8 Oktober 2016. 
dan juga mata kuliah lainnya khususnya bagi perguruan tinggi hukum dapat secara spesifik mata kuliah Hukum Anti Korupsi atau mata kuliah lainnya. Dosen dan mahasiswa juga dapat secara bersama-sama membentuk kader/mahasiswa pelopor anti korupsi baik dalam bentuk pengabdian kepada masyarakat melalui program advokasi dan juga sosialisasi khususnya saat ini yang berkaitan dengan diberikannya anggaran kepada desa untuk dapat mengelola dana desa. Pendampingan dan advokasi ini dapat dilakukan melalui program KKN ataupun program PKL di desa-desa di seluruh wilayah Indonesia sesuai keberadaan perguruan tinggi. Apabila hal ini dapat terpogram dan dilaksanakan dengan baik, maka peran nyata dan manfaat perguruan tinggi dalam menumbuhkan sikap anti korupsi sebagai bagian upaya pencegahan tindak pidana korupsi akan dapat dilihat hasilnya pada kurun waktu 10 (sepuluh) tahun ke depan.

Berdasarkan uraian tentang data siswa-siswa dan mahasiswa tersebut di atas, maka pendidikan sikap anti korupsi sangat efektif untuk dilakukan sebagai upaya konkrit mensosialisasikan sikap anti korupsi sebagai bagian dari upaya pencegahan tindak pidana korupsi. Upaya menumbuhkan sikap anti korupsi sejak dini ini dimaksudkan sebagai upaya untuk mewujudkan penyelenggaraan negara yang anti korupsi dan berbasis keadilan pada masa yang akan datang karena kelak siswa-siswa dan mahasiswa tersebut akan menggantikan generasi yang ada saat ini dalam berbagai profesi yang akan ditekuni baik pemerintah maupun swasta, serta masyarakat pada umumnya.

\section{Penutup}

Berdasarkan uraian tersebut di atas dapat disimpulkan sebagai berikut:

1. Masyarakat dapat berperan serta dalam pencegahan dan pemberantasan tindak pidana korupsi dalam mewujudkan penyelenggaraan negara anti korupsi dan berbasis keadilan sesuai dengan UU Tipikor dan UU KPK, serta peraturan perundang-undangan lainnya. Peran serta masyarakat tersebut dapat dilakukan oleh perguruan tinggi untuk menumbuhkan sikap anti korupsi sebagai bentuk pengabdian kepada masyarakat dengan mensosialisasikan sedini mungkin kepada siswa-siswi SD, siswa-siswi SMP, siswa-siswi SMA, bahkan kepada mahasiswa di perguruan tinggi masing-masing.

2. Mewujudkan penyelenggaraan negara anti korupsi dan berbasis keadilan dapat dilakukan dengan cara menumbuhkan sikap anti korupsi bagi siswa dan mahasiswa melalui kurikulum di setiap tingkatan jenjang pendidikan mulai dari SD, SMP, SMA, dan Mahasiswa dalam beberapa mata pelajaran ataupun mata kuliah tertentu yang memasukkan nilai-nilai sikap anti korupsi. 


\section{Daftar Pustaka}

\section{Buku}

Ahmad Sudiro dan Deni Bram, Hukum dan Keadilan (Aspek Nasional dan Internasional), Cetakan ke-1, Raja Grafindo Persada, Jakarta, 2013.

Agus Santoso, Hukum, Moral, Dan Keadilan Sebuah Kajian Filsafat Hukum, Cetakan ke-1, Prenada Media Group, Jakarta, 2012.

Ani Sri Rahayu, Pendidikan Pancasila \& Kewarganegaraan (PPKn), Cetakan ke-1, Bumi Aksara, Jakarta, 2013.

B. Hestu Cipto Handoyo, Hukum Tata Negara Indonesia, Cetakan ke-5, Universitas Atma Jaya, Yogyakarta, 2013.

Bagir Manan, Politik Perundang-Undangan dalam Rangka Mengantisipasi Liberalisasi Perekonomian, FH-UNILA, Bandar Lampung, 1996.

Bismar Siregar, Hukum Hakim dan Keadilan Tuhan, Gema Insani Press, Jakarta, 1995.

C.S.T Kansil dan Christine S.T Kansil, Empat Pilar Berbangsa Dan Bernegara, Cetakan ke-1, Rineka Cipta, Jakarta, 2011.

Efran Helmi Juni, Filsafat Hukum, Cetakan ke-1, Pustaka Setia, Bandung, 2012.

Ermansjah Djaja, Memberantas Korupsi Bersama KPK (Komisi Pemberantasan Korupsi), Sinar Grafika, Jakarta, 2013.

Indriyanto Seno Adji, Korupsi dan Penegakan Hukum, Diadit Media, Jakarta, 2009.

Lilik Mulyadi, Tindak Pidana Korupsi di Indonesia (Normatif, Teoritis, Praktik dan Masalahnya), PT. Alumni, Bandung, 2007.

Mochtar Kusumaatmadja, Fungsi dan Perkembangan Hukum dalam Pembangunan Nasional, Bina Cipta, Jakarta, 1976.

Muntoha, Negara Hukum Indonesia Pasca Perubahan UUD 1945, Cetakan ke-1, Kaukaba Dipantara, Yogyakarta, 2013.

Otje Salman S., H.R. dan Anthon F. Susanto, Teori Hukum, Mengingat, Mengumpulkan, dan Membuka Kembali, PT Refika Aditama, Bandung, 2004.

Romli Atmasasmita, Globalisasi dan Kejahatan Bisnis, Cetakan Pertama, Kencana Prenada Media, Jakarta, 2010.

Satjipto Rahardjo, IImu Hukum, PT. Citra Aditya Bakti, Bandung, 2000.

Sudargo Gautama, Pengertian tentang Negara Hukum, Penerbit Alumni, Bandung, 1983.

Susi Dwi Harijanti (et.al) (eds), Negara Hukum yang Berkeadilan Kumpulan Pemikiran dalam Rangka Purnabakti Prof. Dr. H.. Bagir Manan, S.H., M.H., Cetakan ke-1, PSKN FH Unpad, Bandung, 2011.

Syahrial Syarbaini, Pendidikan Pancasila (Implementasi Nilai-Nilai Karakter Bangsa) Di Perguruan Tinggi, Cetakan ke-4, Ghalia Indonesia, Bogor, 2012. 


\section{Dokumen Lain}

Biro Pusat Statistik, "Jumlah Sekolah, Guru, Murid Sekolah Dasar (SD) di Bawah Kementerian Pendidikan dan Kebudayaan Menurut Provinsi 2011/20122013/2014", https://www.bps.go.id/linkTabelStatis/view/id/1810, diakses tanggal 8 Oktober 2016.

, "Jumlah Sekolah, Guru, Murid Sekolah Menengah Pertama (SMP) di Bawah Kementerian Pendidikan dan Kebudayaan Menurut Provinsi 2011/2012-2013/2014", https://www.bps.go.id/linkTabelStatis/view/id/1835, diakses tanggal 8 Oktober 2016.

"Jumlah Sekolah, Guru, Murid Sekolah Menengah Atas (SMA)

di Bawah Kementerian Pendidikan dan Kebudayaan Menurut Provinsi 2011/2012-2013/2014", https://www.bps.go.id/linkTabelStatis/view/id/1837, diakses tanggal 8 Oktober 2016.

"Jumlah Perguruan Tinggi, Mahasiswa, dan Tenaga Edukatif

(Negeri dan Swasta) di Bawah Kementerian Pendidikan dan Kebudayaan Menurut Provinsi 2013/2014", https://www.bps.go.id/linkTabelStatis/

view/id/1839, diakses tanggal 8 Oktober 2016.

"Jumlah Perguruan Tinggi, Mahasiswa, dan Tenaga Edukatif

(Negeri dan Swasta) di Bawah Kementerian Agama Menurut Provinsi 2013/2014", https://www.bps.go.id/linkTabelStatis/view/id/1840, diakses tanggal 8 Oktober 2016.

Jhon Rivel, "Membangun partisipasi masyarakat dalam memerangi korupsi", http://www.kompasiana.com/rivel/membangun-partisipasi-masyarakatdalam-memerangi-korupsi_552988646ea8348068552d76, diakses tanggal 30 September 2016.

RB. Soemanto (et.al.), "Pemahaman Masyarakat tentang Korupsi", Jurnal Yustisia, Vol. 88, 2014.

\section{Dokumen Hukum}

Undang-Undang Nomor 28 Tahun 1999 tentang Penyelenggaraan Negara yang Bersih dan Bebas dari Korupsi, Kolusi, Nepotisme.

Undang-Undang Nomor 31 Tahun 1999 tentang Pemberantasan Tindak Pidana Korupsi.

Peraturan Pemerintah Nomor 68 Tahun 1999 tentang Tata Cara Pelaksanaan Peran Serta Masyarakat dalam Penyelenggaraan Negara.

Tambahan Lembaran Negara Republik Indonesia Tahun 1999 Nomor 387. 